\title{
Dialectical Despair: Gherasim Luca, Gellu Naum, and the Hazards of a Non-Oedipal Life Catherine Hansen
}

\author{
"A somnambulist walking upon the roofs has a \\ sacred right not to be called by his name." \\ — Friedrich Nietzsche, letter to Franz Overbeck, 1880.
}

At some point in the year 1945 in Bucharest, the Romanian surrealists Gherasim Luca and Gellu Naum had a quarrel. It was certainly one of many: by this time, the Romanian surrealist group had been active for several years, was in the middle of a prolific publishing streak, and had already seen certain fault-lines deepen between its members. Since their formation as a group they had had little to no communication with Paris or with the wartime surrealist exiles in New York, Breton included. Their last "message," as Naum put it, from Breton was the poem "Pleine Marge," and the last major document of surrealist thought of which they could have been aware was Breton and Trotsky's 1938 "Pour un art révolutionnaire indépendant," which positioned itself not only for a proletarian revolution but against a growing totalitarian current in the USSR. In Romania, in the meantime, the Romanian Communist Party backed by Stalin was gradually increasing its political and economic power, as well as its power of censorship.

This particular dispute centered around the following question: in a society based on division, oppression, and inequality, is love really possible?

This had little to do with whether, in the existing state of things, human beings could meet, court, or make love. Two individuals could of course "fall in love," get married, and lead a comfortable and happy life - one in which, as Luca puts it, they "execută câteva sute de mișcări senzuale și sentimentale care le fixează limitele" (Inventatorul 27) 'execute the few hundred sensual and sentimental motions that define their limits' (Inventor 27). ${ }^{1}$

1 In citations from Inventatorul iubirii I rely both on Julian and Laura Semilian's translation and on my own translations. Citations from "Inventor" are from the Semilians' version. 
What Naum, Luca, and the other group members wondered was whether love is a transformative force that anticipates the free human community for which the surrealist revolution longs and strives, or whether love, entangled within an existing system of power and possession, is already sapped at the root. Could love break free of these few hundred motions, of the ready-made structures of human relation available to it? The stakes of this problem were high, for it opened upon a series of larger, more general questions: can we act to change the foundations of society if we ourselves are fatally meshed within it? Can we speak in criticism of this society if the latter creates the very conditions of possibility for our utterances? Is a position of true critique, of true exception, even possible? And if not, what then?

The funny thing, though, about Luca and Naum's difficult dispute is that they both give the same answer, and for similar reasons, to its central question: yes and no. Upon closer look, there is actually very little to distinguish their positions in the matter. They both make clear, in one way or another, that they stake everything on the possibility that a revolutionary life, and that love as a state of exception, can be realized in the here and now, in the very teeth of the present order. But they both also have their doubts. Both often recount moments of terrible despair, of total loss of confidence in their cause. The heart of the matter, actually, is not the question itself but the fact that each accuses the other of wallowing in this very despair - and of turning and fleeing the "obstacle" of the existing social system and its pervasive power. Even Naum's harsh critique of Luca's "non-oedipal" theory of love and voluptuously revolutionary living, for example, ultimately resolves into a principled objection to what, to Naum, appear to be episodes of bleak hopelessness, without answer or egress, which punctuate Luca's nonoedipal works. As in the popular image of a somnambulist on a tightrope who keeps his balance only so long as he stays asleep, the two describe a narrow, delicate path to be walked between an inescapable world that is and an impossible world to come - one that is very vulnerable to failures of faith. ${ }^{2}$ No matter how mad the love, no matter how revolutionary the life, there are moments when they wake and nearly fall.

\section{Oedipus, Non-Oedipus, and Being Between Circles}

Although both Luca and Naum practice an ars vivendi that enters up and down cycles - of faith in the power of love and suspicion that it is not enough - Luca's is

Inventatorul iubirii is the title of the full volume and also the title of its first section. All in-text citations of Inventatorul or Inventor refer to the full volume and not necessarily to the first section, though the text occasionally refers specifically to individual sections. (It should be noted that Luca's own later French version of Inventatorul iubirii differs in many respects from the Romanian original.)

2 In his Second Manifesto of Surrealism, Breton describes Surrealism as "this tiny footbridge over the abyss," one that must always remain without handrails (Manifestoes 146). 
the more fully elaborated in the immediate post-war era. It would be useful then, before discussing their dispute in detail, to set forth some of the major characteristics and reference points of Luca's approach, having it stand in for both. Luca had been drawing the outlines of a non-oedipal alter ego for some time before 1945, when he unleashed a group of texts all rooted within his developing theory. This was the year that Inventatorul iubirii (The Inventor of Love) was published, along with Un lup văzut printr'o lupă (A Wolf Seen Through a Loupe) and in French, Le Vampire passif (The Passive Vampire). A few of the short and long texts that appear within these volumes were drafted much earlier, or recycled from works that would never see print. These essays, theoretical tracts, and prose poems treat "Oedipus" as a convergence of familial and socio-cultural power and oppression. For the most part they do not engage in detail with the Oedipus complex in its Freudian elaboration, but abstract from Freud's work certain clear positions of attack.

Luca's Oedipus stands first of all for memory, for the past in its determination of the present, and for the irremediable and complementary facts of birth and death. It is the trauma of birth as well as the fear of death that accompanies it. Oedipus also stands for castration, which for Luca includes everything that reduces an experiential or perceptual content to a fixed identity or significance. To reduce for example, as psychoanalysis does, the manifest and concrete images of a dream to a few well-worn symbols and latent patterns, a few traumatic memories, is an act of castration.

Oedipus is a repressive, censoring power residing not only in social categories and familial structures but also in the very biological make-up of the human. Its world is not only one of "ready-made love affairs, of fatal complexes, of limits" but also of "women and men" (Inventor 19). In Inventatorul iubirii Luca writes, "Detest acest fiu natural al lui Oedip, urăsc și refuz biologia lui fixă" (Inventatorul 14) 'I detest this natural son of Oedipus, I hate and refuse his fixed biology.' In an exhibition catalog composed with fellow group-member D. Trost, Luca writes that their comportment vis-à-vis the "exterior" world is one of a "refus de regarder comme une réalité objective l'axiomatique condition humaine, même sous ses aspects apparement immuables" (Graphies colorées) 'refusal to regard the axiomatic human condition as an objective reality, even under its apparently immutable aspects. ${ }^{3}$ The axiomatic human condition is the oedipal condition; it is everything

3 The unpaginated catalog is Présentation de graphies colorées, de cubomanies et d'objets, accompanying a January 1945 exhibition at Sala Brezoianu in Bucharest in which only Luca and Trost participated. An additional note on refusal: Luca exclusively uses the formulation "non-oedipal" rather than "anti-oedipal," the formulation more familiar perhaps to readers of Deleuze and Guattari. On occasion in this essay I do use the term "anti-oedipal," having "anti" stand in for simple negation as opposed to dialectical negation, a distinction discussed in detail below. 
that hinders the free and transformative expression of love, down to the gendered body itself.

The struggle against Oedipus is not only a personal but also a political matter, for Oedipus is what undermines any attempt at revolutionary change. Luca writes for example that a married proletarian, or one who admires his father, will fail in his revolutionary efforts because he carries the "microbe" of the family within his blood. And because all of society teems with such microbes, it is nearly impossible not to become infected in some way: one's efforts to escape Oedipus are, for the most part, oedipal. This is what Luca calls the vicious circle. The imagination itself is pinioned by a "biologia crispată a omului" (Inventatorul 24) 'cramped human biology,' and even dreams may not be enough, since they are withered by the programmatic smallness of waking life, and thus impoverished can no longer enrich it. It is not simply that all revolutionary impulses will fall in one way or another into oedipal triangulations or hierarchies, but that they have already fallen, just as love, despite itself, is already its own oedipal parody.

It is because the vicious circle operates so effectively that there is no sense in asking whether one should first "change life" and then "transform the world," or the other way around. ${ }^{4}$ As far as Luca is concerned this is a misleading chickenand-egg problem. Instead one must act diffusely, simultaneously within life and world: "liberarea omului o văd strâns legată de simultaneitatea soluțiilor și să nu mi se spună că trebue făcută mai întâi revoluția socială și numai după aceia o vom face pe aceia morală, etc. . . ." (Inventatorul 24) 'I see the liberation of man inexorably connected to the simultaneity of all solutions, and please don't tell me that the social revolution must be accomplished first and only then the moral one, etc. . . .' (Inventor 25). What this simultaneity implies is that among the most "variate aspirațiuni revoluționare . . . trebue să-și facă loc chiar cele mai depărtate ca felul de a ne pieptăna, de a săruta, de a privi" (Inventatorul 24) 'disparate revolutionary aspirations ... we must make room for the most diverse, such as the manner in which we comb our hair, kiss one another, gaze at each other' (Inventor 26). ${ }^{5}$ And for Luca, the name of this diffuse, daily, and liberated means of being is non-Oedipus.

The non-oedipal position is, however, one that refuses names first of all. In passing moments, certainly, non-Oedipus experiments with various labels, or gives himself over entirely to the states of being and modes of behavior associated with them, but they don't stick. Luca's non-Oedipus will often speak the word "I,"

4 For these phrases I am thinking of the conclusion of Breton's 1935 Speech to the Congress of Writers: "'Transform the world,' Marx said; 'change life,' Rimbaud said. These two watchwords are one for us" (Manifestoes 241).

5 See also Breton, in the Second Manifesto of Surrealism: "I am in fact awaiting, not my day, but, if I may use the term, our day, the day when all of us will recognize one another by this sign, that we do not swing our arms when we walk the way the others do - have you noticed, even those of us most in a hurry?" (137). 
but this " $\mathrm{I}$ " is so multiple and attracts so many predicates and attributes as to be meaningless according to ordinary standards. He refuses not only to be named or to name himself but also to fix, in its ideological or socio-cultural place, any object with which he comes into contact, or any gesture or habit associated with that object. He is a mobile and fluid thing among many shifting mobilities. To every thing that is "ready made" he opposes invention, and to every singular identity he attaches a series of potentially infinite variations. What seems a permanent feature of reality is always only one permutation of elements among many. "I am forced," Luca writes,

să inventez un mod de a umbla, de a respira, de a exista, pentrucă lumea în care mă mișc nu e nici de apă, nici de aer, nici de pământ, nici de foc ca să știu dinainte că trebue să înot sau să sbor sau să calc în două picioare. Inventând al cincilea element, al șaselea, sunt silit să-mi revizuesc ticurile, obișnuințele, certitudinile. . . A patra dimensiune (5, $6,7,8,9)$ al cincilea element $(6,7,8,9,10,11)$ al treilea sex $(4,5,6,7)$. (Inventatorul 12)

to invent a new mode of ambulation, of breathing, of being, because in the world through which I circulate there is neither water nor earth, neither air nor fire, to warn me beforehand if my means of locomotion should be swimming or flying, or whether I should step forward with both feet. Inventing the fifth element, the sixth, I am forced to revise my compulsions, my customs, my certitudes. . . . The fourth dimension $(5,6$, $7,8,9)$ the fifth element $(6,7,8,9,10,11)$ the third sex $(4,5,6,7)$. (Inventor 17-18)

Nothing about him is natural. There is no image of the human or even of the biological human body to which he conforms. Instead certain objects, organs, functions, or capabilities graft themselves upon him briefly, then dissolve to be replaced by others. He walks the streets wearing on his back a pipe organ whose keys are pressed by vultures and bats, or wearing lungs pinned to his chest like a medal, or wearing a third eye on his forehead. ${ }^{6}$ Luca might have found more than one precedent (though, as he declares, he will accept no precedents or predecessors) for this performative freedom of the first person pronoun. In Lautréamont's Les Chants de Maldoror, for example, the presiding voice declares: "Sur ma nuque, comme sur un fumier, pousse un énorme champignon, aux pédoncules ombellifères. ... Mes pieds ont pris racine dans le sol et composent... une sorte de végétation vivace ... qui ne dérive pas encore de la plante, et qui n'est plus de la chair" (CEuvres 151-52) 'From my nape, as from a dungheap, sprouts an enormous toadstool with umbelliferous peduncles.... My feet have taken root in

6 These examples are taken from Un lup văzut printr'o lupă (A Wolf Seen Through a Loupe), which was published separately from Inventatorul iubirii. In the Semilians' translation, Inventatorul and Un lup appear in a single volume; passages from Lup are cited as "Inventor." 
the soil forming a sort of perennial vegetation - not quite plant-life though no longer flesh' (Maldoror 142). What was once his (or its) body is home to toads, chameleons, hedgehogs, and jellyfish who have come to replace the organs and parts. The self-transformations of non-Oedipus also recall the personages described by the Romanian writer Urmuz, a powerful inspiration to the Romanian avant-garde of the twenties, thirties, and beyond. These figures are composed of bits of clothing and debris, sewer gratings, sideburns, piano lids, and dead insects, and drip with oil and soot, like sordid bionic suburbanites.

But Luca's non-Oedipus is more fluid and more permeable, always releasing and receiving flows, charges, breaths, and subtle magnetisms. His is a phenomenology of arousal; everything happens on the "plane" of excitation and erotic anticipation. What occurs on this "plane" is not only fully real but is an open door toward other potential realities. In Le Vampire passif he writes:

Je mange, je respire, je bois, je pense, je nie, je m'habille, je me meus aphrodisiaquement. Je garde chacune de mes cellules dans un état de permanente excitabilité, excité et excitant à chaque instant, les zones qui traversent mon être sont génitales et prégénitales, érotiques et criminelles.... (Vampire passif 55)

I eat, breathe, drink, think, reject, dress myself and move aphrodisiacally. I keep every cell of my being in a state of permanent excitation, excited and exciting at the same time, the zones traversing my being are genital and pregenital, erotic and criminal. . . (Passive Vampire 89) ${ }^{7}$

He roams the streets preying upon everyone and everything in the world and being preyed upon in turn, exquisitely sensitive to all premonitions, solicitations, impressions and coded messages. He is like a more than ordinarily lucid sleepwalker: everything he encounters enters his dream and is transformed by it.

But sometimes, Luca-as-non-Oedipus loses his balance. And when he does, memory, identity and common sense rush, like the ground, to meet him. Or rather, as he recounts it, he falls away from the enchanted non-oedipal circle that had made him immune from such things, and the delirious, amphibious world in which he moves sharpens into focus as simple pain: "a ceaseless physical oppression within my chest, as if someone were taking bites from it." What he feels in such moments is:

7 With Luca's "les zones qui traversent mon être" one cannot help but think of certain passages from Deleuze and Guattari's Anti-Oedipus, for example the following: "The breasts on [Judge Schreber's] naked torso are neither delirious nor hallucinatory phenomena: they designate, first of all, a band of intensity, a zone of intensity on his body without organs. The body without organs is an egg: it is crisscrossed with axes and thresholds, with latitudes and longitudes and geodesic lines, traversed by gradients marking the transitions and the becomings, the destinations of the subject developing along these particular vectors" (19). 
marea, monstruoasa decepție pe care mi-o provoacă propriul meu personagiu, drogat de ideia că parcurge cu o agilitate nemaiîntâlnită granița dintre somn și trezie, dintre da și nu, dintre posibil și imposibil, ca să se pomenească dintr'odată față în față cu reversul propriei sale medalii într'o lume de iluzii deșarte, de jocuri subiective și de erori fundamentale care nu iartă și care transformă inegalabila și inimaginabila mea existență într'o rană. (Inventatorul 83-84)

the great, the monstrous disillusion that my own personage provokes in me - drunk on the idea that with unparalleled agility he strides along the border of sleep and waking, of yes and no, of possible and impossible, only to come to himself all at once, face to face with the other side of his own coin, in a world of empty delusions, subjective games and fundamental errors that do not forgive and that transform my incomparable and indescribable existence into a wound.

It is as if the colossal virtuosity of his self-transformations - the immense height of his tightrope - make his loss of balance all the more drastic. Suddenly the world can no longer be reinvented but simply is how it is. It is how the father, the doctor, the butcher, the banker, and the bureaucrats always said it was. He is not dancing above the world, but is crushed beneath it. He finds himself suddenly "într'o cameră înghețată, flămând, singur, murdar, cu virtualitatea trădării oedipiene în toate umbrele mele, bolnav, uitat, mizerabil, tremurând de frig și de frică. . . ." (Inventatorul 84) 'in a frozen room, hungry, alone, dirty, with the virtuality of Oedipal betrayal in all of my shadows, sick, forgotten, wretched, shaking with cold and fear....'

It is here in this frozen room that Gellu Naum finds him. In a small tract titled "Inventatorii banderolei" ("The Inventors of the Banderole") ${ }^{8}$ - which devotes itself almost entirely to opposing Luca's recent work - Naum uses these and similar passages to make the argument that Luca's non-oedipal activity and theory, which Naum refuses to associate in any way with surrealism, represent not only a dangerous error, but an utter failure. He points toward these very moments of despair and questioning as evidence that Luca has taken an entirely wrong and reactionary path. Luca had written, in "Moartea moartă" ("Death Dead," the third section of Inventatorul iubirii):

Eșecul aparent al activității mele non-oedipiene tindea să mă arunce de viu în ghiarele unei răspândite erori de gândire care îi face pe cei mai agitați dintre revoluționari să afirme: în societatea împărțită în clase este irealizabilă iubirea, suportându-i în mod mecanic tirania sau evaziunile sublimate și uitând că unica posibilitate de a păstra eficacitatea

8 The Romanian word banderolă can refer to either a small pennant or streamer, a band of paper surrounding a wrapped package or a new book, or an armband or brassard used to indicate military rank, political affiliation, or physical disability. 
insurecțională a unei asemenea afirmații este negarea imediată a ororii pe care o conține și a dominației ei paralizante. (Inventatorul 114-115)

The apparent failure of my non-oedipal activities was apt to throw me alive into the claws of a widespread error of thought that causes the most agitated among revolutionaries to affirm: in a society divided into classes, love is unattainable, for it supports in mechanical fashion this society's tyranny and evasive sublimations, while forgetting that the single possibility of preserving the insurrectional efficacy of such an affirmation is the immediate negation of the horror it contains and of its paralyzing dominance.

This is how Naum, quoting the passage above, responds:

Fără a-mi face iluzii de ceiace poate însemna pentru d-sa [Luca] "revoluționar" nu-mi este greu să mă recunosc printre cei de mai sus, mai ales în această afirmație care făcuse cu un an sau doi în urmă pivotul contradicțiilor noastre. Ceiace îl îngrijorează aici pe d. G. L. este posibilitatea - deloc justificată în ceiace ne privește - ca o asemenea constatare să fie privită ca o fatalitate și suportată ca atare. Teama aceasta de a nu suporta tirania unei asemenea afirmații, sau evaziunile sublimale la care ea are putea duce, teama de a nu pierde astfel "eficacitatea insurecțională" este aceia pe care o resimte în mod special d. G. L. ("Inventatorii" 89)

Without entertaining any illusions as to what "revolutionary" might mean for [Luca], it is not hard for me to recognize myself among those mentioned above, particularly in this affirmation that for a year or two had been the pivot of our contradictions. What so troubles G.L. here is the possibility - not at all justified as far as we are concerned - that an observation like this might be seen as a matter of fate, and tolerated as such. This fear of not being able to endure the tyranny of such an affirmation, or the evasive sublimations that it could lead to, the fear of thereby losing one's "insurrectional efficacy," is what G.L. feels in a special way.

For Luca, however, it is precisely the temporary breakdown of his non-oedipal machine that makes him recoil in despair before this "affirmation." And the curious thing is this: he doesn't actually say that one should ignore or negate the affirmation itself - the affirmation being that love is too vitiated by the society in which it takes root to ever act as a socially transformative force. What he says is that one must negate that which, within this affirmation, leads to resignation, paralysis, and despair. At the same time one should accept it, but only insofar as it motivates continuing insurrectional action and sets the non-oedipal apparatus in motion. If indeed he had Naum in mind among the "agitated revolutionaries," it is Naum he accuses of having failed to do so. Naum, in turn, makes almost the 
same point: that it is possible to recognize the truth of this "affirmation" without making oneself helpless before it. It is Luca, he says, who is afraid to confront it directly and flees into non-oedipal sophistries and solipsisms. Again, the actual content of the non-oedipal project, similar in so many respects to Naum's own experimentations, does not seem to be at issue.

In Gellu Naum's Zenobia, published in 1985 but working in some ways as a summation of his life and thought as a surrealist, a person named "Gellu" encounters a woman, both uncanny and innocent, who like a medium is sensitive to and can occasionally manipulate the world's dark and invisible lines of force. Together the two live through the power of their disponibilitate: their availability, receptivity, openness, in the sense in which Breton uses the word disponibilite in $L^{\prime}$ Amour fou.$^{9}$ Theirs is a world of serenity and of mysterious certitudes; they play upon the strings of chance and cultivate special "states" (stări) that straddle inner and outer, subjective and objective domains. Like Luca-as-non-Oedipus, "Gellu" stands to the side of the certainties and categories of social life. As he shouts at a nice young woman from the Department of Classical Philology at the University of Bucharest, "nu mă amesteca în nici o tagmă, nu uita . . . să nu-mi pui etichete, mă sufoc, dacă rostesc un nume din cărțile nenorocite pe care mi le aduci îmi și găsești o etichetă; . . . să știi că nu trăiesc pentru și contra, ca în capcana voastră . . . Să știi că eu sînt în afară" (Zenobia 1985, 108-109) 'don't put me in any category whatsoever . . . don't put labels on me, I'll suffocate, if I utter a name from those miserable books that you're bringing me, you'll immediately find a label for me ... remember that I don't live pro and con, like in your trap. . . . Remember that I am outside' (Zenobia 1995, 78). But just as for Luca, there is another side to this coin. In Zenobia it is called revanşa: the retaliation, the requital. It is what happens when a state, or a confidence, or a vision has been too powerful - like a rip current flowing back seaward. Naum describes it as a void, a panic, a spiritual catalepsy, or rather a "divorce between my consciousness and my factual existence" where "each plane seemed capable of literally pulverizing any temptation to escape from their common game." The nature of this "revansa generală" is abruptly to take and occupy the place of "the poetic miracle in the world" (Zenobia 1995, 119-120).

An early example of this experience is when "Gellu" and Zenobia are wintering in a tiny hole in a concrete dam in a swamp:

[E]ram neliniștit, nu mai aveam pic de încredere în mine, în tot ce văzusem, îmi venea să plîng, să-i spun Zenobiei: “Nu vezi ce nenorocit sînt, în bezna și în noroiul ăsta? Unde e dragostea lumii, unde e dragostea ta? nu vezi că plasticul ăla împuțit cu care ești îmbrăcată e rece, și nici nu mă iubești măcar, dacă m-ai iubi ai face și tu ceva ca să termin cu nervii

9 "Still today I am only counting on what comes of my own openness (disponibilité), my eagerness to wander in search of everything, which, I am confident, keeps me in mysterious communication with other open beings, as if we were suddenly called to assemble" (Mad Love 25). 
rațiunii și cu neîncrederea asta, m-ai scăpa din scorbură, am sta și noi, ca oamenii, lîngă un calorifer încălzit, ne-am plimba cu liftul sau am intra într-un magazin luminos, mi-aș cumpăra tutun irlandez, pentru pipă, nu așa, în mizerie, cu cizmele sparte și cu ciorapii uzi și înghețați, nu vezi? . . . îmi pipăiam fruntea murdară de pămînt și îmi venea să mor . . . . (Zenobia 1985, 30-31)

I was angry, I didn't have the least confidence in myself, in all I had seen, I felt like crying, I felt like telling Zenobia: “Can't you see how miserable I am, in this darkness and mud? Where is the world's love, where is your love? Can't you see that the smelly plastic you're wearing is cold, and you don't even love me, if you did you would do something to help me get over my fit of reason and distrust, you would rescue me from this hollow, and we too would live, like human beings, next to a warm radiator, we would ride the elevator, or we would go into a bright store, I would buy myself Irish tobacco for my pipe, not like this, in poverty, with my broken boots and my wet and frozen socks, can't you see? . . I I touched my forehead soiled with dirt and I felt like dying. . . . (Zenobia 1995, 18-19)

Zenobia, who herself hovers somewhere between phantasm and flesh, at first fails to speak words of comfort to him. Though she so often weaves around him a "protective aura," even she is sometimes vulnerable to his doubts. In one later episode, for example, Gellu muses: "Dacă la început muncile ei silnice, într-un sordid atelier de decorațiuni . . . mi se păreau menite să acopere o viață prea strălucitoare, acum vedeam în ele un fel de resemnare" (Zenobia 1985, 128-129) 'if, at first, her hard labors in a sordid novelty shop . . . seemed meant to cover too brilliant a life, now I saw in them a sort of resignation' (Zenobia 1995, 92). But when Zenobia finally breaks her silence, she tells him to calm down. "You were between circles," she says, "on the edges, in the void, it's all over now."

In those moments when Gellu and Zenobia find themselves in opposition, it is because of his "transient departure from the circles"; in experiences like the one in their winter burrow, he has fallen outside or between these "circles." The two spend a great deal of their time connected, quite literally, at the shoulder, but outside the "circle" they are no longer so. In Inventatorul iubirii and elsewhere, Luca speaks of a "medium-lover" who is also, upon occasion, attached to his shoulder. ${ }^{10}$ This lover "allows herself to be frantically consumed by the flames of the magic circle within which the nefarious acts of my thought processes unfold." "Mediumistically" moved from afar, she creates and sends to him objects which are "cu desăvârșire insesizabile dacă nu sunt privite dinăuntrul acestui cerc,

\footnotetext{
10 See for example in Un lup văzut printr'o lupă: "the woman I seek is close by my shoulder"
} (Lup 7), or “I raise you upon my shoulder...." (Lup 12). (Inventor 69, 71). 
dinăuntrul acestor acte și ale acestei gândiri" (Inventatorul 58) 'absolutely ungraspable if not perused from within the circumference of this circle, from within the circumference of these acts and these thoughts' (Inventor 38). ${ }^{11}$ The circle, then, whatever its nature, is the means by which love works directly in and upon the world and its objects, transforming their substance. Inside the circle, one leads a brilliant life of non-oedipal refusal and metamorphic love in which everything is portent and potential; outside the circle is the mud and the cold, or the dirty little room. It is true that both within and without the circle, one finds the same little rooms and the same intractable world with its same obstacles. But to be within the circle is to act, and to fall outside the circle is to despair of acting.

\section{The Rose that isn't a Rose, and Dialectical Despair}

Although Naum and Luca's dispute now seems even less like a dispute, Naum has not yet said all he has to say in the matter. The plot thickens: Not only does Naum charge Luca with escapism and resignation, but he also claims that the latter has not fully understood the concept of negation, particularly in the context of dialectics. Luca's efforts, he writes, are falsely dialectical because they fail to go beyond what he calls simple negation. For this reason Naum takes particular issue with a phrase that appears often in Luca's work and especially in the texts and tracts co-written with Trost: "negaţia negatiei" (the negation of negation.) The phrase is a Hegelian technical term, 12 a fact of which Naum and Luca were both aware. But more importantly for Naum, it is a concept within Marxist philosophy and theory. In his critique, Naum quotes a passage from Friedrich Engels's AntiDühring in which Engels defends Marx against accusations of using "dialectical mazes" and "Hegelian contortions" to support his ideas. Engels provides a brief summary of the ways in which certain stages of historical or economic development - for example the rise of the capitalist mode of production - can create or contain the conditions for their own eventual undoing. For example, one begins with the common ownership of land and the productive arrangements that arise naturally from it. Eventually this common ownership itself becomes a "fetter" on these arrangements, so it is "negated" and transformed into private property. And when private property in turn, in the same way, becomes a fetter on its own modes of production, a demand arises for its negation. This is the negation of the negation. This new development, however, would not be a return

11 As to these mediumistic procedures, Luca elaborates: to discover that "without my knowledge I had a desire which I sent mediumistically to my lover has become for [me] the certitude and an objective consequence of an objective amorous rapture which is impossible for me not to compare with the results obtained through any other objective method which arouses the visionary, active and real functioning of thought" (Inventor 37). "Me" is omitted in the above translation, and I include it in brackets.

12 For a discussion of this concept see for example the sections "The Negation of Negation" and "Change and Self-Relation" in Houlgate, 2006 (317-30). 
to the original state of things, to the original common ownership, but "the institution of a far higher and more developed form of possession in common" (Engels 135). The negation of negation is not a return but a sublation; and it is no sophistical contortion of thought, but a general law, like a physical law of motion, that presides over everything from barley seeds to calculus to the upheavals of history, by which every determinate state contains the embryo of what will succeed or abolish it.

This is not to say, however, that just any kind of abolishing or negating works in this way. Someone might point out for example that "I negate the sentence, the rose is a rose, when I say: the rose is not a rose; and what do I get if I then negate the negation and say, but after all the rose is a rose?" (Engels 136). Nothing much, to be sure. It would be, Engels adds, painfully infantile to do so. Negation in dialectics is not simply saying no and then saying yes again or, for that matter, declaring something null or destroying it. One must:

so construct the first negation that the second remains or becomes possible. . . If I grind a grain of barley, or crush an insect, it is true that I have carried out the first part of the action, but I have made the second part impossible. Each class of things therefore has its appropriate form of being negated in such a way that it gives rise to a development. (136)

In "Inventatorii banderolei," perhaps better called "Anti-Luca," Naum makes use of this same distinction, and even quotes Engels's rose example. At best Luca's "negation of negation," he writes, is nothing but a sequence of simple, reversible negations, a childish game of peekaboo in which the rose is, is not, and is again. At worst it is nothing more than the repeated crushing of insects:

[A]ceastă negație a negației nu poate să ducă decât la falșa poziție a negărei simpliste a peisajului, a naturii, a iubirii biologice, a complexelor, a poeziei, în sensul lor cel mai comun, sens cu care se răsboiesc încă dd. G. L. T. ("Inventatorii" 94)

[T]his negation of negation can lead nowhere except to the false position of the simplistic negation of the landscape, of nature, of biological love, of the complexes, of poetry, all in their most common sense, the sense against which G.L.T. is still at war. ${ }^{13}$

Naum also calls André Breton to his assistance in the matter. "Inventatorii banderolei" is strongly informed and guided by Breton's Second Manifeste du surréalisme (1930), going so far as to adopt its militant, irascible tone. This second manifesto is, among other things, an apologia for a decisive surrealist turn to the social and to a questioning "of the social regime under which we live, I mean of the acceptance or the nonacceptance of this regime" (139). Here Breton proclaims

13 "G.L.T." is Gherasim Luca and Trost bundled into a single entity. 
surrealism's allegiance to Marxist thought and to historical materialism, but wonders why a thought "finally made tractable to negation, and to the negation of negation" should need to restrict itself to the economic or social (140). He wants, in other words, to dramatically expand the scope of this form of thought, and flourishes Engels's (and Naum's) rose as a prop for his argument. Bored with an idea that starts with point $\mathrm{A}$, proceeds to its opposite pole at point $\mathrm{B}$ and returns, gravid with $B$, to point $A$ - and not to mention with the rose that is and is not a rose - Breton suggests another procedure:

... entraîner la "rose" dans un mouvement profitable de contradictions, moins bénignes où elle soit successivement celle qui vient du jardin, celle qui tient une place singulière dans un rêve, celle impossible à distraire du "bouquet optique," celle qui peut changer totalement de propriétés en passant dans l'écriture automatique, celle qui n'a plus que ce que le peintre a bien voulu qu'elle garde de la rose dans un tableau surréaliste, et enfin celle, toute différente d'elle-même, qui retourne au jardin. (Manifestes 90)

. . . to lure "the rose" into a movement pregnant with less benign contradictions, where it is, successively, the rose that comes from the garden, the one that has an unusual place in a dream, the one impossible to remove from the 'optical bouquet,' the one that can completely change its properties by passing into automatic writing, the one that retains only those qualities that the painter has deigned to keep in a Surrealist painting, and, finally, the one, completely different from itself, which returns to the garden. (Manifestoes 141)

Since there should be nothing, in other words, that limits the negation of negation to a spiraling but bilateral movement between points $A$ and $B$, however dialectical this movement may be, Breton would like to relay the rose through as many letters of the alphabet as possible before returning it transformed to the garden.

As far, however, as Luca and Trost are concerned in their 1945 critical manifesto "Dialectics of the Dialectic," one might as well not return the rose to the garden at all. Here the two argue that surrealism should never at any moment rest upon its laurels or roses, or fall into any habits and patterns. Surrealism cannot remain in a "continually revolutionary state" unless it practices a permanent negation of negation; it must exist in "continual opposition to the whole world and to itself" and immediately "trample underfoot" any discovery or desire which does not lead to a new discovery or desire, in a chain of constant invention. There is never any return: "Ces états de négation qui s'enchaînent concrètement, absurdement et dialectiquement l'un à l'autre, nous font rejeter le passé dans son entier" (Dialectique 16) 'each state of negation, linked one to another in a concrete, absurd and dialectical way, causes us to reject the past in its entirety' ("Dialectics" 35-36). What for Luca and Trost is a ferocious engine of destruction and invention 
seems, despite Naum's accusations, to have little to do with Engels' rose, blinking in and out of existence.

What, then, of the idea that all of Luca's insurrectional energy, his non-oedipal refusal of fixed biology and ready-made love, is no more than a simple negation, a matter of empty wishful thinking? For this is what Naum would like his readers to believe, and this he feels is the source of Luca's despair. It would be like the despair of a child who wishes his parents didn't exist and keeps finding that, in fact, despite everything, they do. The rose is not a rose, is a rose, is not a rose: an alternation of simple negation and simple despair. It is not my goal primarily to show that Naum is wrong about Luca - that, at least here, he has sorely misunderstood him, whether deliberately or not. What I would like to show is how Naum's argument about negation returns decisively to the question of love outlined above.

It does no good for the child to "negate" his parents, or for a revolutionary, positioning himself as "anti"-oedipal, to negate the order of things, because in both cases the two are connected. The child exists because his parents do and is a product of their parenting, just as what is anti-Oedipus is a product of its oedipal society. What is wrong with Luca's project, as Naum understands it, is that Luca doesn't see this connection: he sees the individual and the social, the personal and the historical, as two separate and immiscible spheres in confrontation, most often to the detriment of the first. In such an arrangement, the most this isolated individual can do is either accept the terms offered to him, or turn away with an indignant "no," or one that alternates between the "no" of private fantasy and the "no" of despair.

But this situation is exactly the danger against which Luca consciously struggles. To accept without question, he writes, that the "biological rhythms of humans may differ from the rhythm of historical liberation" would force us to "manifestly recognize our powerlessness" before the oedipal obstacle, would make of the revolution a mere wish-fulfillment fantasy and would place an impenetrable theoretical barrier between desire and its realization (Inventor 64). To act upon the supposition that life rhythms and historical rhythms are out of sync by positioning oneself as powerless would make a revolution only of the mind, the imaginary and utopian mirror-image of an intractable reality, and would demote desire to the status of a compensatory daydream. The real problem, actually, is that they are in sync. It is not, he makes clear, that we are not in some sense powerless. It is not that desire meets no obstacles to its realization. But the key insight is that anti-Oedipus and oedipal society, ${ }^{14}$ desire and its obstacles,

14 Breton calls it "bourgeois society": "a certain man, who sees himself as a revolutionary, would like to convince us that love is impossible in a bourgeois society; some other pretends to devote himself to a cause more jealous than love itself; the truth is that almost no one has the courage to affront with open eyes the bright daylight of love in which the obsessive ideas 
imply each other. Luca's formulation of the vicious circle - in which love, for example, cannot act as a transformational force because its resources are no more than those made available to it in the society against which it sets itself - is already a recognition of this connection and bears witness to its profundity. While a desire that merely wishes the erasure of its obstacle takes the stance of simple negation, the vicious circle holds the place of a negation of this negation, showing how this first simple negation contains its own collapse. The danger, as Luca puts it, of falling into a "formal and logical despair" is the danger of a simple negation in which this fact is not recognized. To suffer from this "formal and logical despair" is to helplessly wish that the obstacle didn't exist without realizing that one is part and product of it.

If simple negation is precisely this helpless gesture or wish, then the negation of negation is the realization, on the part of the one performing this gesture, that he also "negates" himself in doing so. If society has to start all over again, so does he.

Everything, writes Luca, "must be reinvented," even oneself. In this way what was once an obstacle is now an endless field of potential action. If simple despair is a result of simple negation, then from the negation of negation follows dialectical despair, which understands this first despair as part of the very structure of the vicious circle, and which takes as its object this new field of action.

Something of this approach appears in Breton's Second Manifesto, which along with L'Amour fou deeply affected the work of the Romanian surrealist group as a whole. Without despair, he writes - and not despair as paralysis or resignation but despair as a cry of revolt and insubordination - it is impossible truly to believe in "the gleam of light that Surrealism seeks to detect deep within us" (Manifestoes 126). Surrealist despair neither fully accepts nor fully rejects the state of things which provokes this cry of revolt:

Si, par le surréalisme, nous rejetons sans hésitation l'idée de la seule possibilité des choses qui "sont" et si nous déclarons, nous, que par un chemin qui "est," que nous pouvons montrer et aider à suivre, on accède à ce qu'on prétendait qui "n'était pas," . . . comment veut-on que nous manifestions quelque tendresse, que même nous usions de la tolérance à l'égard d'un appareil de conservation sociale, quel qu'il soit? Ce serait le seul délire vraiment inacceptable de notre part. Tout est à faire, tous les moyens doivent être bons à employer pour ruiner les idées de famille, de patrie, de religion. (Manifestes 77)

If through Surrealism, we reject unhesitatingly the notion of the sole possibility of the things which 'are,' and if we ourselves declare that by a

of salvation and the damnation of the spirit blend and merge, for the supreme edification of man. Whoever fails to remain in this respect in a state of expectation and perfect receptivity, how, I ask, can he speak humanly?" (Manifestoes 180). 
path which 'is,' a path which we can show and help people to follow, one can arrive at what people claimed 'was not' . . how do you expect us to show any tenderness, even to be tolerant, toward an apparatus of social conservation, of whatever sort it may be? That would be the only madness truly unacceptable on our part. Everything remains to be done, every means must be worth trying, in order to lay waste to the ideas of family, country, religion. (Manifestoes 127-28)

There are at least two options that follow the initial cry of revolt. The first is to start walking in the other direction, away from the obstacle, on the path of "what is not." This would be the path of simple negation and simple despair. The other is, after the cry of revolt, to turn not away from but decisively back toward "what is," both rejecting and following its path. If in the "first" negation desire and revolt appear as fantasies operating in parallel and in counterposition to "what is," in the second negation - the negation of negation - they place themselves back within the world. Or rather, they recognize that they are already there. If the interimplication of revolt against society and society itself, of anti-Oedipus and Oedipus, is what makes the vicious circle so formidable, this is also what might disarm it. For if there is such a connection, such an inter-implication, then desire does not stand somewhere in the sidelines crying out its opposition, but is already in the game, right at the very heart of present reality. This is what Luca is saying when he writes that "realizarea relativ-absolută a dorințelor în mijlocul societății contemporane surprinsă la granița propriilor ei contradicții, e singura care ne pune în contact cu societatea fără clase" (Inventatorul 115) 'the relative-absolute realization of desire in the middle of contemporary society, surprised at the border of its own contradictions, is the only means to get in contact with the classless society.' (Inventor 64). This takes place through "a perpetual breach into the exterior world. ${ }^{15}$

Nothing at all, says Luca, love included, is possible - be it breathing, using a fork, smiling, or dreaming. There is no "power of love" that could stand separate from the world and act, just as to abstract a fork from this world would make it meaningless. ${ }^{16}$ Nothing can take place in its fullness, for absolutely everything is caught up in the same vicious circle. But this is not a cause for despair. It is not

${ }^{15} \mathrm{He}$ is saying, as Deleuze and Guattari might put it, that "if desire produces, its product is real. If desire is productive, it can be productive only in the real world and can produce only reality" (26).

16 Instead, Luca makes the fork a point of extraordinary and direct contact: "I touch a fork and unleash an entire network of possibilities, a very complicated machine [maşină] is set in motion as if the fork were a factory of questions, of impulses and spectres, a door opens inside it leading toward a hallway. ..." He goes on to speak of "the strictly forbidden entrance of that set of dentures, the back-door exit of the window or the service door entrance of the stones, look, all the possibilities of doing exactly the opposite of everything that imposes itself upon us" (Inventor 98-99). Translation slightly modified. 
love versus the world but love in the world that simultaneously rejects and follows the path of "what is." Luca's (and Naum's) amorous revolutionaries, like somnambulists, dream the revolution as they walk down the crowded streets of the real. For Luca it is by "disperând disperarea" - "despairing [his] despair," accepting that nothing can be done and still doing, thus finding an escape from the "ferocious teeth of negation" - that he manages "an unhoped-for capture and devouring of the real" (Inventatorul 116; Inventor 65). He believes that where there is a command there is a defiance; where there is a determination there is a negation; and where there is a prison there is an exit.

\section{Works Cited}

Breton, André. Mad Love. Trans. Mary Ann Caws. Lincoln: U of Nebraska P, 1987. Print.

—. Manifestes du surréalisme (Paris: Gallimard, 2007). Print.

Manifestoes of Surrealism. Trans. Richard Seaver and Helen R. Lane. Ann Arbor: U of Michigan P, 2007. Print.

Deleuze, Gilles, and Félix Guattari. Anti-Oedipus: Capitalism and Schizophrenia. Trans. Robert Hurley, Mark Seem, and Helen R. Lane. Minneapolis: U of Minnesota P, 2005. Print.

Engels, Friedrich. "The Negation of the Negation." Reader in Marxist Philosophy: From the Writings of Marx, Engels and Lenin. Ed. Howard Selsam and Harry Martel. New York: International Publishers, 1963. 133-37. Print.

Gherasim Luca. Inventatorul iubirii, urmat de Parcurg imposibilul şi de Moartea moartă.

Bucharest: Negația Negației, 1945. Print.

- The Inventor of Love $\mathcal{E}$ Other Writings. Trans. Julian and Laura Semilian. Boston: Black Widow, 2009. Print.

- Un Lup văzut printr'o lupă. Bucharest: Negaţia Negației, 1945. Print.

. The Passive Vampire: with an introduction on the Objectively Offered Object.

Trans. Krzysztof Fijałkowski. Prague: Twisted Spoon, 2008. Print.

- Le Vampire passif: Avec une introduction sur l'objet objectivement offert. Paris: José Corti, 2001. Print.

Gherasim Luca and Trost. Présentation de graphies colorées, de cubomanies et d'objets. Bucharest: Sala Brezoianu, 1945. Print.

. "Dialectics of the Dialectic: A Message addressed to the International Surrealist Movement." Surrealism Against the Current: Tracts and Declarations. Ed. Krzysztof Fijałkowski and Michael Richardson. London: Pluto, 2001. 3536. Print.

- Dialectique de la dialectique: Message adressé au mouvement surréaliste international. Bucharest: S Surréalisme, 1945. Print.

Houlgate, Stephen. The Opening of Hegel's Logic: from Being to Infinity. West Lafayette: Purdue UP, 2006. Print. 
Lautréamont, Comte de [Isidore Ducasse]. CEuvres complètes. Ed. Pierre-Olivier Walzer. Paris: Gallimard, 1970. Print.

. Maldoror $\mathcal{E}$ the Complete Works of the Comte de Lautréamont. Trans. Alexis Lykiard. Cambridge: Exact Change, 1994. Print. Bibliothèque de la Pléiade, 218.

Naum, Gellu. "Inventatorii banderolei." Teribilul interzis. Bucharest: Colecția Suprarealistă, 1945. 87-96. Print.

—. Zenobia. Bucharest: Cartea Românească, 1985. Print.

- Zenobia. Trans. James Brook and Sasha Vlad. Evanston, Illinois:

Northwestern UP, 1995. Print.

Urmuz [Demetru Dem. Demetrescu-Buzău]. The Complete Works of Urmuz. Trans. Miron and Carola Grindea. London: Atlas, 2006. Print.

Copyright (C) 2015 Catherine Hansen 